実験ノート

\section{NBSにおける化学分析の 標準試料について}

\section{石井大道*}

\section{NBS の 概 況}

NBS (National Bureau of Standards, 米国標準局)は 商務省に属し，1901年に創立された国立の研究機関で， 創立以来首都ワシントン市内にあったが数年前に新し い施設が， ワシントン市から約 20 マイル北西の郊外 Maryland 州の Gaithersburg 地区に, 約 230 万平方メ一 トルの広い敷地をもって建設され，米国に挑ける近代的 な研究所の一つとなっている. 研究所の一部は Colorado 州の Boulder にもあり約 3500 名の所員をもっている. この研究所の主な任務は, 化学, 物理学, 工学, 工業お よび商業の各分野で必要な，各種測定の基礎となる標準 物質と標準データおよび各種の物理測定法の確立, 制 定，その維持などに関する仕事である。そして商務省の みでなく, 米国政府の各機関との連けいを保ち, 基礎科 学, 応用科学, 工学および技術の広い分野にわたって活 動している. 研究所の中は Institute と Center に分けら れ，その下に各 Division があり Division の中にはいく つかの Section が置かれている，その内容は第1表のよ らであり, NBS が測定や標準についての綜合的な研究 機関であることがわかる。

第 1 表 NBS の 部 門 内 容

\section{NBS の標準比較物質について}

NBSは，古くから各種の標準試料を調製し，米国抒 よび各国に供給していることで有名である。わが国にお いても，化学分析のチェックなどに広く利用されてき た. 以前は標準試料 (Standard Samples) といら名で, 化 学成分の分析值をつけた各種の鉱石，鉄鋼などが供給さ れていたが，今日では 670 種類以上の各種の試料が， “標準比較物質 (Standard Reference Materials, 略して SRM)” との名称で, 単に化学分析値を付した標準試料 といら意味のみでなく，各種の物理的性質および測定の 基準として，さらに工学的な標準物質なども含んで供給 されるよらになってきた。 たとえば，陪休化学用標準， 核物質標準，メッキ厚久標準，ガラス粘度標準，高分子 材料の分子量標準, 熱的性質の標準, 光学的性質の標準, 放射能標準, Mössbauer 化学シフト標準. 治金学的標準 および動植物中の微量元素分析の標準などのように，最 近の科学技術の進歩ならびに社会的な要求に関連して各 種の標準物質が調製，市販されるようになった。 これら SRM についての詳細は，そのカタログ(1)が発行されて いるので必要なおは

Office of Standard Reference Materials,

National Bureau of Standards,

Washington D.C. 20234 U.S.A.

に直接請求されると，無料で送付してくれる.

ここでは，比較的新しく作られた金属材料関係の SRM の主なものを第 2 表に紹介する.

これら金属関係の SRM の多くは，製造会社の協力に よって作製され，その表示分析値はNBS，各製造会社秥

\begin{tabular}{|c|c|}
\hline $\begin{array}{l}\text { The Institute for Basic } \\
\text { Standards }\end{array}$ & $\begin{array}{l}\text { Office of Measurment Services, Applide Mathematics, Electricity, Metrology, } \\
\text { Mechanics, Heat, Atomic and Molecular Physics, Radio Physics, Radio Engi- } \\
\text { neering, Time and Frequency, Astrophysics, Cryogenics }\end{array}$ \\
\hline $\begin{array}{l}\text { The Institute for } \\
\text { Material Research }\end{array}$ & $\begin{array}{l}\text { Office of Standard Reference Materials, Analytical Chemistry, Polymers, } \\
\text { Metallurgy, Inorganic Materials, Physical Chemistry }\end{array}$ \\
\hline $\begin{array}{l}\text { The Institute for } \\
\text { Applide Technology }\end{array}$ & $\begin{array}{l}\text { Engineering Standard, Weights and Measures, Invention and Innovation, } \\
\text { Vehiche System Research, Product Evaluation, Building Research, Electronic } \\
\text { Technology, Technical Analysis, Measurement Engineering }\end{array}$ \\
\hline $\begin{array}{l}\text { The Center for Computer } \\
\text { Sciences and Technology }\end{array}$ & $\begin{array}{l}\text { Information Processing Standards, Computer Information, Computer Services, } \\
\text { System Development, Information Processing Technology }\end{array}$ \\
\hline $\begin{array}{l}\text { The Office for Informa- } \\
\text { tion Programs }\end{array}$ & $\begin{array}{l}\text { Office of Standard Reference Data, Office of Technical Information and Publi- } \\
\text { cations, Library, Office of Public Information, Office of International Relations }\end{array}$ \\
\hline 名古屋大学教授; 工学 & $\begin{array}{l}\text { (1) "Catalog of Standard Reference Materials" NBS } \\
\text { Special Publication } 260 .\end{array}$ \\
\hline
\end{tabular}


第 2 表比較的新しい金属関係のSRM

\begin{tabular}{|c|c|}
\hline SRM 361 366 & $\begin{array}{l}\text { 低合金鋼 (AISI 4340, } 94 \text { B 17, Cr-V 鋼, 高炭素鋼) および電解鉄。化学分析用，チ } \\
\text { ップ状 }\end{array}$ \\
\hline SRM $661 \sim 668$ & $\begin{array}{l}\text { SRM 361 366 と同じ. ェレクトロンプローブ, レーザプローブ, スパークソース } \\
\text { 質量分析など微量機器分析用, 直径 } 3.2 \mathrm{~mm} \text {, 長さ } 51 \mathrm{~mm} .\end{array}$ \\
\hline SRM 1095 & $\begin{array}{l}\text { AISI } 4340 \text {, 酸素分析 (真空融解法, 不活性ガス融解法および高速中性子放射化法) } \\
\text { 用, 酸素 } 9 \mathrm{ppm} \text {, 直径 } 6.4 \mathrm{~mm} \text {, 長さ } 102 \mathrm{~mm}\end{array}$ \\
\hline SRM 1096 & $\begin{array}{l}\text { AISI } 94 \text { B 17, 酸素, 窒素分析用, 酸素 } 10 \mathrm{ppm} \text { ，窒素 } 40 \mathrm{ppm} \text {, 直径 } 6.4 \mathrm{~mm} \text {, } \\
\text { 長さ } 102 \mathrm{~mm}\end{array}$ \\
\hline SRM 1099 & 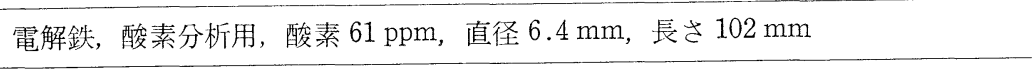 \\
\hline SRM $1261 \sim 1266$ & $\begin{array}{l}\text { SRM } 361 \sim 366 \text { と同じ，発光分光分析，X線スペクトル分析に使用するための標準, } \\
\text { 直径 } 31 \mathrm{~mm} \text {, 厚さ } 19 \mathrm{~mm}\end{array}$ \\
\hline SRM 1134 & 高ケイ素鋼，直径 $31.8 \mathrm{~mm}$, 厚さ $19.1 \mathrm{~mm}$ \\
\hline SRM 1256 & 同上, チップ状 \\
\hline SRM 1171 & Cr 17-Ni 11-Ti 0.3, AISI 321, 直径 $31 \mathrm{~mm}$, 厚さ $19 \mathrm{~mm}$ \\
\hline SRM $121 \mathrm{~d}$ & 同上, チップ状 \\
\hline SRM 1172 & Cr 17-Ni 11-Nb 0.7, AISI 348, 直径 $31 \mathrm{~mm}$, 厚さ $19 \mathrm{~mm}$ \\
\hline SRM $123 \mathrm{c}$ & 同上，チップ状 \\
\hline SRM 1206 1209 & $\begin{array}{l}\text { 高温合金(Rene } 41 \text {, Waspaloy, Inco 718) X線スペクトル分析, 発光分光分析用, } \\
31 \mathrm{~mm} \times 31 \mathrm{~mm} \times 19 \mathrm{~mm}\end{array}$ \\
\hline SRM 531 & 鉛ベース，ベアリング用合金，粉末 \\
\hline SRM 1132 & 同上, 直径 $31.8 \mathrm{~mm}$, 厚さ $19 \mathrm{~mm}$ \\
\hline SRM $654 \mathrm{a}$ & チタン合金, $6 \mathrm{~A} 1-4 \mathrm{~V}$ 直径 $31 \mathrm{~mm}$, 厭さ $6.4 \mathrm{~mm}$ \\
\hline SRM 483 & $\mathrm{Fe}-3 \% \mathrm{Si}$ 合金, マイクロプローブ用標準, $3 \mathrm{~mm} \times 3 \mathrm{~mm} \times 0.28 \mathrm{~mm}$ \\
\hline SRM $166 \mathrm{c}$ & 低炭素ステンレス鋼，(AISI 316 L) 炭素分析用，炭素 $0.0078 \%$, 粉末状 \\
\hline SRM 485 & Ferrite 中の Austenite $(4 \%)$, X線回折用，直径 $21 \mathrm{~mm}$ ，厚さ $2.5 \mathrm{~mm}$ \\
\hline SRM 493 & Spheroidized Iron Carbide (Ferrite 中) X線回折用, $29 \mathrm{~mm} \times 29 \mathrm{~mm} \times 2.5 \mathrm{~mm}$ \\
\hline
\end{tabular}

よび他の研究機関での分析結果を統計的に処理して決 定している. NBS では Office of Standard Reference Materials (チーフはJ.Paul Cali)とAnalytical Chemistry Division (チーフはDr.W.Wayne Meinke) が協力 して SRM の調製および分析の実施などを行なってい る. Analytical Chemistry Division には 9 の Section が あり, 各種の機器分析および化学分析の研究がそれぞれ の専門家によってなされている。筆者は 1970～71 年に 客員研究員として滞在したが，その間に見たところで は, Analytical Chemistry Division の研究者, 技術者 の姫とんど全員(約 100 名)が各種 SRM に関係した新し い分析法の研究ならびに分析值の決定に従事しているよ

らであった。

第 2 表の中で, SRM 361〜366, SRM 661〜668, SRM
1095 1099, SRM 1261 1266 は同じ原材料から作られ たものであり，それぞれ化学分析用，微量機器分析用， 酸素および窒素分析用, X線および発光分光分析用に調 製されている。これら一連のSRM の作り方について担 当者である R.E.Michaelis 氏から聞いたところによる と, これらは約 5 トンのインゴットを幅 18 インチ, 厚 さ 6 インチ, 長さ 20 フィート程度に圧延した後, インゴ ットでの上部，下部执よび中心部に相当する組成が不均 一な部分それぞれ約 15\%ずつを取り除き，残りの部分 について組成の均質さを多数の分析によって調べて確か めた後，これを適当に切断して SRMとして慎重に作製 しためのであるとのことであった，このように比較的大 きいインゴットの中の組成が均質な部分を用いて，それ ぞれ目的とする分析方法に適した試料の形状に整形調製 
するといら方法は, 金属材料の標準試料を作る力法とし て合理的で興味深い.

\section{3. 研究物質と一般物質}

最近ではSRMのほかに研究物質(Research Materials, 略してRM) と一般物質 (General Materials, 略して GM) と名付けられるものが NBS から供給されるようになっ た. RMには超純粋アルミニウム単結晶 (RM 1 C) および 同多結晶(RM 1 R) があり, これらは固体物理学などの各 研究者の共通の研究用標準物質として用いられることを 期待している。また GM はNBS 以外の政府機関, ASTM (American Society for Testing Materials), ANSI (American National Standard Institute), ISO (the Organization for International Standardization)などで 作られた標準物質で，とくに工業上必要とするものを
NBS が世話をすることにしたものである.これには， GM 1 および GM 2 として鋼中の水素の標準があり，こ れは英国の The Welding Institute in Cambrige から出

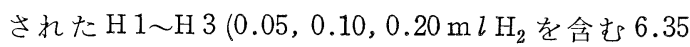
$\mathrm{mm} \phi \times 30 \mathrm{~mm}$ 約 $6 \mathrm{~g})$ 扎よび $\mathrm{H} 4 \sim \mathrm{H} 6(0.20,0.60,1.10$ $\mathrm{m} l \mathrm{H}_{2}$ を含む $12.7 \mathrm{~mm} \phi \times 30 \mathrm{~mm}$, 約 $22 \mathrm{~g}$ ) に相当する ものである。

\section{4. 環境分析用の SRM}

公害問題に関連して, 環境分析関係の標準としては, 最近, 空気中の炭化水素 (SRM 1610 1613), 亜硫酸ガス の permeation tube(SRM 1625 1627), 果樹の葉の中の 各種微量元素(SRM 1571), 牛の肝臓中の各種微量元素 (SRM 1577)などが，それぞれ調製されている.

(1972 年 12 月 11 日受理)

\section{一分科会報告—}

真空治金シンポジウム

\section{(第総合分科)}

昭和 47 年 11 月 14,15 の両日, 早稲田大学鋳物研究所 において, 日本鉄鋼協会との共催のもとに, 「真空冶金 シンポジウム」を開催した. 真空冶金に関係している研 究者, 技術者が集まり, 情報の交流, 問題点の認識などを 通じて, 研究, 技術の発展に寄与する場を持つことが目 的であったが，昭和 48 年 6 月には第 4 回真空治金国際 会議が東京で開催されることにもなって打り，国内のこ の方面に対する関心が高まっている折から，約 150 人に の㳯る参加者が集まり活発な発表, 討論が行なわれた。

日程の都合上，真空冶金全般にわたる問題は 4 篇の招 待講演により行ない, (a) 真空冶金に関する基礎的研究, (b) 真空製錬，真空精製，(c)エレクトロスラグリメルテ イング, の 3 分野について一般講演を公募して企画した が, 予定した 1 日半では不足気味な内容であった。

第 1 日目の午前中は, 前記 4 件の招待講演が行なわれ た. 東大宇宙航研の大島耕一氏は宇宙空間に淤壮る真空 中で人工衛星や宇宙船の構成物質が，ぞのような状態に さらされ，どんな污染を受けるか，またそれをどのよう な地上実験でテストするかを説明された。地上で小さな 真空空間を造り出すのに波々としているわれわれにとっ て，無限の真空空間に物質を持ち込んでの話しは甚だ興 味深いものがあった。

電子総研の伊藤沼夫氏は, 超高温材料の真空蒸着之題 し, 薄膜技術が Protective coating からさらに進んで, 新しい機能特性を開発する手段としても重視されてきて いることを説明され，薄膜作製のスパッタ法，蒸着法な どにそれぞれ目的に応じた工夫がこらされていることが 理解された。
日本真空技術の林 主税氏は, 真空中の特殊溶解鋳造 について講演され, 従来から挙げられている各種方法に ふれられたが，とくにデルファイ法による技術予測で, これら溶解鋳造法がどのように位置づけられ，期待され ているかについて子解説された。

阪大溶接研の荒田吉明氏は従来のアーク溶接法に比肩 しらるものとして, 将来真空中での電子ビーム, レーザ ビーム，特殊プラズマビームなどによる超高エネルギ密 度溶接法が重視されることを, 理論, 実際の両面にわた り懇切に解説された.

ついで一般講演にらつり，第 1 日目午後の前半は非鉄 金属の真空治金関連する発表が行なわれた，東海大の 黄燕清氏らは真空治金と関連の深い $\mathrm{V}, \mathrm{Nb}, \mathrm{Ta}, \mathrm{Mg}$ な ぞの金属中の水素の測定法と溶解平衡につき発表し, 京 大の小野勝敏氏らは金属ニオブの製造精製の基礎となる $\mathrm{Nb}-\mathrm{C}-\mathrm{O}$ 系の高温挙動の実験につき発表した。また金材 技研の亀谷氏らは銅溶錬に拈ける溶融粗銅やマットを真 空吸上精製した場合の研究結果をまとめて報告した。

第 1 日目午後の後半から第 2 日目のはじめにかけて, 鉄関係の真空処理に関する報告が 6 篇発表された。まず 大同中研の手塚広吉氏らは高ニッケル合金をプラズマ 誘導溶解する際の脱水素とスラグによる脱硫脱酸につい。 て報告した。ついで日新周南の桑野知矩氏らは減圧下で ステンレス溶鋼を酸素上吹きし脱炭する際の脱窒反応に つき，また日本冶金川崎の渡辺哲弥氏らは減圧下で高ク ロム鋼浴を処理した際のガス-融体，ガスースラグ反応に よる脱炭につき報告を行なった。つぎに神鋼中研の森谷 清氏らが電子衝撃融解法により高クロム鋼を溶解精製す る際の諸成分の挙動につき発表し，新日鉄広畑の佐伯 毅氏らは高級厚板用キルド鋼の製造に RH 法を適用する 場合の予備脱酸の程度と非金属介在物の挙動との関係に 主眼を置いて，有効な実施法を確立した経緯を報告し た．さらに日本特殊鋼の金原 茂氏らが高級鋼を真空ア 